\title{
Interstitial lung disease and asthma in hard-metal workers: bronchoalveolar lavage, ultrastructural, and analytical findings and results of bronchial provocation tests
}

\author{
AG DAVISON, PL HASLAM, B CORRIN, II COUTTS, A DEWAR, WD RIDING, PR \\ STUDDY, AJ NEWMAN-TAYLOR
}

From the Brompton Hospital and Cardiothoracic Institute, London; Bedford General Hospital; and Harefield Hospital

\begin{abstract}
Five patients with respiratory disorders associated with hard metal exposure are described. In four patients electron microprobe analysis of bronchoalveolar lavage cells or lung tissue was used to show tungsten and other hard-metal components. Three patients had interstitial pneumonia and fibrosis with unusual multinucleate giant cells. Electron microscopy showed that the giant cells comprised both type II alveolar epithelial cells and alveolar macrophages. The multinucleate macrophages formed a distinctive feature of the bronchoalveolar lavage material but the multinucleate alveolar epithelial lining cells were evident only in lung tissue. The other two patients both suffered from work-related asthma, one of whom also had pulmonary opacities. Bronchial provocation tests in these patients supported the diagnosis of hard-metal-induced asthma and implicated cobalt as the agent responsible.
\end{abstract}

Hard metal is an alloy of tungsten carbide, cobalt, and occasionally other metals such as titanium and tantalum. Because of its hardness and resistance to high temperature it is used to make drill tips, tool edges, and armament components. In the manufacturing process the raw materials are ball milled and the resultant dry powder is mixed with wax, pressed into moulds, and heated to $1000^{\circ} \mathrm{C}$ (presintering). The presintered hard metal has the consistency of chalk and can be easily cut into the required shape. The shaped article is then heated to about $1500^{\circ} \mathrm{C}$ (sintering) to produce hard metal, which can be worked only with a diamond. Ball milling, working the presintered metal, and grinding the sintered product are all processes liable to produce dust.

Respiratory disease in the hard-metal industry has been recognised as a probable occupational hazard since 1940.' The initial reports emphasised interstitial lung disease but more recently asthma has also been described. ${ }^{23}$ We have recently investigated five hard-metal workers with modern techniques and have obtained new information on lung diseases

Address for reprint requests: Dr AJ Newman-Taylor, Brompton Hospital, London SW3 6HP. associated with hard metal. Of particular interest are our ultrastructural, microanalytical, and bronchoalveolar lavage findings and the results of bronchial provocation tests.

\section{Methods}

The techniques of bronchoalveolar lavage and differential cell counting of the lavage cell samples have been described previously. ${ }^{4}$ For transmission electron microscopy the lavage cells were fixed in suspension in $2.5 \%$ glutaraldehyde in cacodylate buffer, osmicated, and processed to Araldite. For electron microprobe elemental analysis, Aralditeembedded sections, $5 \mu \mathrm{m}$ thick, of non-osmicated lavage cells were mounted on carbon stubs, carbon coated, and examined without further treatment in a scanning electron microscope equipped for energy dispersive $x$-ray analysis, dust particles being identified from their back-scattered electron images. Cell-free lavage fluid samples and urine were examined for cobalt by atomic absorption spectroscopy.

Lung tissue was examined by light microscopy, transmission electron microscopy, and microprobe 
elemental analysis. For both light microscopy and elemental analysis, 5- $\mu \mathrm{m}$ paraffin sections of lung tissue fixed in commercial formalin were used. These were stained with haematoxylin and eosin and elastin van Gieson for light microscopy or mounted on carbon stubs, deparaffinised, and subjected to elemental analysis as described above. For transmission electron microscopy, fresh lung tissue was fixed in cacodylate-buffered glutaraldehyde followed by osmium tetroxide and processed to Araldite, and ultra thin sections were stained with uranyl acetate and lead citrate.

Occupational type dust inhalation tests were made by the method of Davies et al..$^{5}$ A decrease of $15 \%$ from the baseline forced expiratory volume in one second $\left(\mathrm{FEV}_{1}\right)$ after a lactose control test was considered a positive response to the challenge.

\section{Case reports}

\section{CASE 1}

A 35-year-old man was well until March 1979, when 17 months after starting work grinding presintered hard metal he developed a dry cough and exertional dyspnoea without wheeze. Previously he had been a lorry driver, and he had never smoked. D桴ing a two-week holiday away from work his symptoms improved. Vitalograph recordings at his place of employment showed that his $\mathrm{FEV}_{1}$ and forced vital capacity (FVC) had been normal when ge started to work with hard metal and eight months later, but after 25 months he had developed ${ }_{a}$ restrictive ventilatory defect (January 1980: tabجe 1).

He was admitted to hospital in June 1980 f investigation. There were no abnormalities on examination, but the results of lung function tests had deteriorated further (table 1). He showed fio reaction to common inhalant allergens in skin prick tests or to cobalt in a patch test. His chest radiggraph was normal. Haemoglobin concentration, total and differential white cell counts, and erythrocyte sedimentation rate in one hour (ESR) were normal. Serum IgG, IgA, and IgE concentrations were normal, but the IgM concentration was 472 $\mathrm{IU} / \mathrm{ml}$ (normal 58-197). Avian precipitins were detected and an autoantibody screen showed onlyoa weakly positive response to the rheumatoid facegr test. Antibodies to measles virus were not detected by complement fixation tests. There was no increase

Table 1 Lung function tests in case 1

\begin{tabular}{|c|c|c|c|c|c|c|c|c|}
\hline & $\begin{array}{l}\text { Predicted } \\
\text { value* }\end{array}$ & $\begin{array}{l}22 \text { Nov } \\
1977\end{array}$ & $\begin{array}{l}7 \text { Aug } \\
1978\end{array}$ & $\begin{array}{l}4 \text { Jan } \\
1980\end{array}$ & $\begin{array}{l}12 \text { June } \\
1980\end{array}$ & $\begin{array}{l}14 A u g \\
1980\end{array}$ & $\begin{array}{l}22 \text { Sept } \\
1980\end{array}$ & $\begin{array}{l}31 \text { Mar } \\
1981\end{array}$ \\
\hline $\begin{array}{l}\mathrm{FEV}_{1}(\mathrm{ml}) \\
\text { FVC }(\mathrm{ml}) \\
\text { FEV/FVC }(\%) \\
\text { Total lung volume }(\mathrm{ml}) \\
\text { Residual volume }(\mathrm{ml}) \\
\text { Alveolar volume }(\mathrm{ml}) \\
\text { Kco }\left(\mathrm{mmol} \mathrm{min}^{-1} \mathrm{kPa}^{-1} \mathrm{l}^{-1}\right)\end{array}$ & $\begin{array}{l}3290-4450 \\
4030-5480 \\
73-85 \\
5390-7300 \\
1570-2130 \\
5020-6790 \\
1.49-2 \cdot 02\end{array}$ & $\begin{array}{r}4000 \\
5100 \\
78\end{array}$ & $\begin{array}{r}4200 \\
5300 \\
79\end{array}$ & $\begin{array}{r}2200 \\
2700 \\
81\end{array}$ & $\begin{array}{r}1820 \\
2540 \\
72 \\
3630 \\
1130 \\
2800 \\
1 \cdot 55\end{array}$ & $\begin{array}{r}2250 \\
2790 \\
81 \\
4300 \\
1500 \\
4050 \\
1 \cdot 58\end{array}$ & $\begin{array}{r}1960 \\
2370 \\
83 \\
4020 \\
1470 \\
3310 \\
1 \cdot 51\end{array}$ & $\begin{array}{r}2340 \\
2960 \\
79 \\
4320 \\
1520 \\
3780 \\
1 \cdot 48\end{array}$ \\
\hline Occupational exposure & & \multirow{2}{*}{\multicolumn{3}{|c|}{ Working with hard metal }} & \multicolumn{2}{|c|}{$\begin{array}{l}\text { Off work from } \\
3 \text { June }\end{array}$} & $\begin{array}{l}\text { Re- } \\
\text { exposure } \\
\text { for } 4 \\
\text { days }\end{array}$ & None \\
\hline Prednisolone dose (mg/day) & & & & & \multicolumn{2}{|c|}{60} & 20 & 10 \\
\hline
\end{tabular}

${ }^{*}$ From Cotes. ${ }^{29}$

Table 2 Bronchoalveolar lavage observations in cases 1, 2, and 5

\begin{tabular}{|c|c|c|c|c|c|c|c|c|}
\hline \multirow[t]{2}{*}{$\begin{array}{l}\text { Case } \\
\text { No }\end{array}$} & \multicolumn{2}{|c|}{$\begin{array}{l}\text { Total } \\
\text { nucleated cells } \\
\text { recovered }\left(\times 10^{\circ}\right)\end{array}$} & \multicolumn{4}{|c|}{ Differential count (\%) } & \multicolumn{2}{|c|}{ Total macrophages } \\
\hline & $\begin{array}{l}\text { Absolute } \\
\text { No }\end{array}$ & $\begin{array}{l}\text { Nolml } \\
\text { fluid }\end{array}$ & Neutrophils & Eosinophils & Lymphocytes & Macrophages & $\begin{array}{l}\text { With refractile } \\
\text { dust particles }\end{array}$ & $\begin{array}{l}\text { Form } \\
\text { giant }\end{array}$ \\
\hline $\begin{array}{ll}1 & \begin{array}{l}\text { June } 1980 \\
\text { August } 1980 \\
\text { April } 1981\end{array} \\
2 & \\
5 & \end{array}$ & $\begin{array}{l}200 \cdot 88 \\
323 \cdot 90 \\
154 \cdot 88 \\
185 \cdot 22 \\
13 \cdot 93\end{array}$ & $\begin{array}{l}1 \cdot 67 \\
2 \cdot 02 \\
1.41 \\
2 \cdot 47 \\
0 \cdot 63\end{array}$ & $\begin{array}{r}0 \\
0 \\
1 \\
0 \\
71\end{array}$ & $\begin{array}{l}6 \\
0 \\
1 \\
6 \\
0\end{array}$ & $\begin{array}{l}2 \\
0 \\
4 \\
3 \\
1 \cdot 7\end{array}$ & $\begin{array}{l}92 \\
98 \\
92 \\
91 \\
25\end{array}$ & $\begin{array}{r}10 \\
13 \\
26 \\
3 \\
21\end{array}$ & $\begin{array}{r}6 \\
15 \\
2 \\
4 \\
0\end{array}$ \\
\hline $\begin{array}{l}\text { Normal control } \\
\text { ranges }\end{array}$ & $7 \cdot 70-152 \cdot 60$ & $0.06-1.27$ & $0-4$ & $0-3$ & $0-11$ & 41-99 & & \\
\hline
\end{tabular}


in $\mathrm{FEV}_{1}$ after inhaled bronchodilators and his peak flow rate (PEFR) showed no diurnal variation. When the patient had been away from work for eight weeks the findings at fibreoptic bronchoscopy were normal but bronchoalveolar lavage showed that macrophages constituted $92 \%$ of the total cells, eosinophils $6 \%$ and lymphocytes $2 \%$ (table 2). Ten per cent of the macrophages had scanty cytoplasmic particles, which were refractile but not birefringent; and $6 \%$ of the macrophages were bizarre multinucleate giant cells, often with as many as 20 nuclei (fig 1). No mitotic figures were observed. Electron microscopy confirmed that most of the cells were macrophages rather than alveolar epithelial lining cells and that the giant cells also had the features of macrophages (fig 2). Some of the giant cells contained other macrophages within their cytoplasm (fig 3). Elemental analysis of lavage cells showed tungsten and iron. Cobalt was not detected in either lavage cells or fluid.

The patient had an open lung biopsy of the right middle lobe two weeks later. This showed alveolar filling by numerous large mononuclear cells and a few eosinophils (fig 4). Some of the intra-alveolar cells were multinucleate. The alveolar walls were moderately thickened by oedema, macrophage and lymphocyte infiltration, and mild fibrosis. There was hyperplasia of the alveolar epithelium and in many places these cells were columnar or formed multinuclear giant cells (fig 5). No inclusion bodies were identified. Occasionally granulation tissue polyps occluded the bronchiolar lumen. Little dust was evident in the lung on light microscopy and no granulomas were observed. Transmission electron microscopy confirmed that the large intra-alveolar

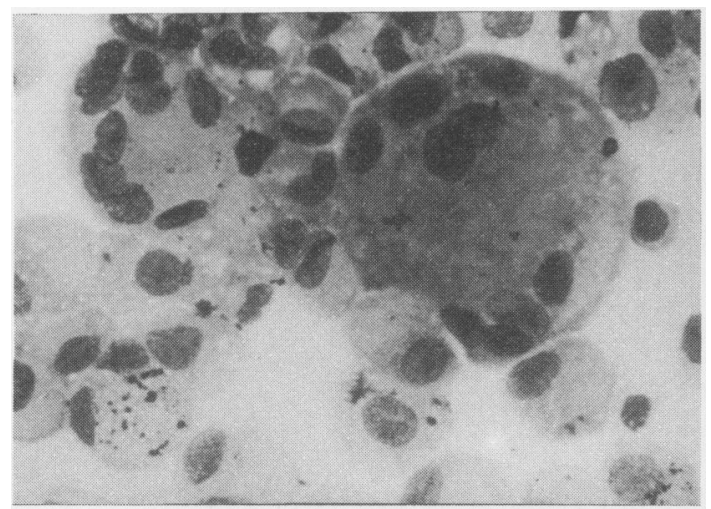

Fig 1 Cytocentrifuge preparation of bronchoalveolar lavage cells showing macrophages with particulate inclusions and bizarre multinucleate giant cells. (May-Grünwald-Giemsa, $\times$ 865.) cells were macrophages, that there was hyperplasia of type II alveolar epithelial lining cells, and that there were multinucleate type II alveolar epithelial cells (figs 6, 7). Dust particles in alveolar macrophages showed abundant tungsten on electron microprobe analysis. Particles containing iron, aluminium, silicon, magnesium, and occasionally titanium were also found but no cobalt was detected.

The patient was started on $60 \mathrm{mg}$ prednisolone a day, and remained away from work, with symptomatic improvement. Five weeks later his lung function had improved (table 1) and bronchoalveolar lavage was repeated (table 2). At this stage eosinophils had disappeared and nearly all the cells were macrophages $(98 \%)$. Particulate cytoplasmic inclusions, many refractile, were evident in $13 \%$ of the macrophages. Bizarre multinucleate macrophages accounted for $15 \%$ of the macrophages. Microprobe elemental analysis showed tungsten and titanium. Prednisolone was reduced to $20 \mathrm{mg}$ a day over the next three weeks. The patient continued to improve and he decided to return to work with hard metal. He became short of breath and lung function tests, performed four days later, showed deterioration (table 1). He changed his job and has subsequently had no further contact with hard metal.

In March 1981 he had been taking prednisolone $10 \mathrm{mg} /$ day for three months but still complained of slight exertional dypsnoea. His chest radiograph remained normal but his lung function, although

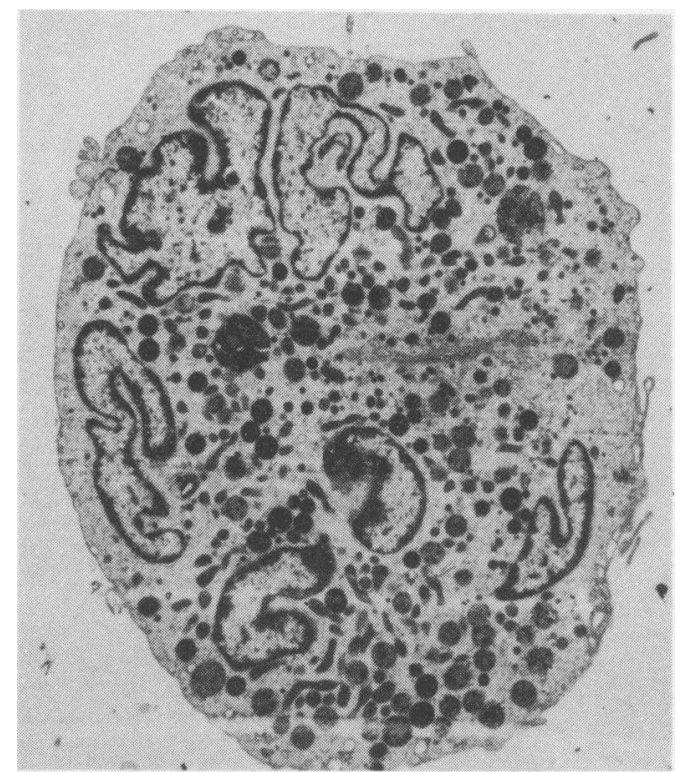

Fig 2 Multinucleate macrophage in lavage material. (Electron micrograph, $\times 3600$.) 


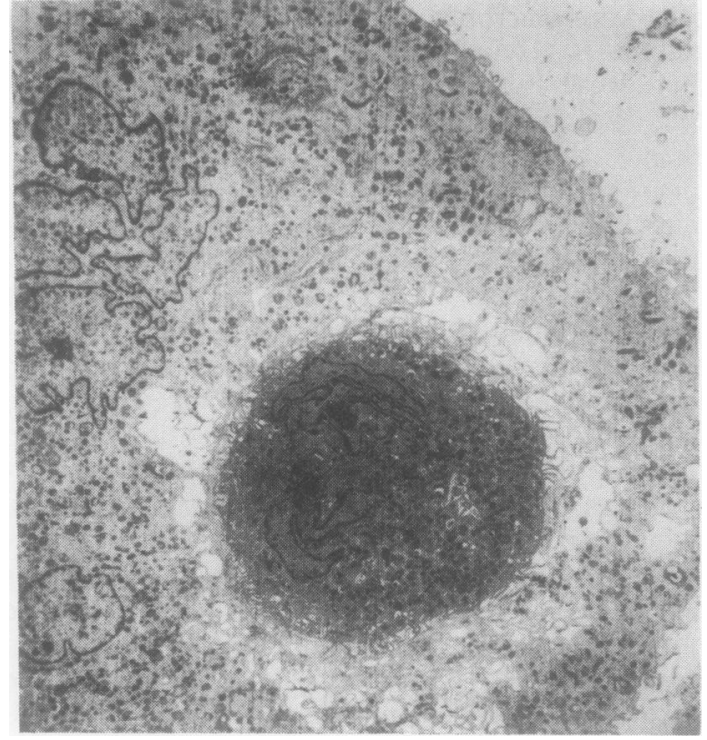

Fig 3 Lavage material showing a multinucleate macrophage containing another macrophage within its cytoplasm. (Electron micrograph, $\times 2000$.)

improved, still showed a predominantly restrictive ventilatory defect (table 1). A third bronchoalveolar lavage was performed (table 2). Most of the cells were macrophages $(92 \%)$, with occasional neut- rophils $(1 \%)$, eosinophils $(1 \%)$, and lymphocyt $\overrightarrow{\text { F }}$ (4\%). Cytoplasmic inclusions were evident in $26 \%$ of the macrophages. In contrast to the previous las age samples, only $2 \%$ of the macrophages were mut:tinucleate. Microprobe elemental analysis show $\overrightarrow{\mathrm{G}}$ tungsten, iron, and occasionally titanium. Cobalt was not detected in the fluid or urine tested at thfe same time.

\section{CASE 2}

A 28-year-old man, a non-smoker, presented with one-year history of increasing shortness of breath There had been considerable deterioration over the last six weeks culminating in breathlessness at rest He had worked as a tool grinder since he was $\overrightarrow{16}$ years of age and had used a hard-metal grinding wheel. His chest radiograph was normal but lung function tests showed that his FEV 1 was 1670 m (predicted 3380-4580 ml), FVC $2230 \mathrm{ml}$ (predicteid $4060-5490 \mathrm{ml}$ ), and transfer factor $45 \%$ of the predicted value. He left work and after nine weeks his symptoms had improved considerably and he was short of breath only after climbing two flights of stairs. At no time had he received any medication There were no abnormalities on examination. H haemoglobin concentration, total and differenti white cell counts, and erythrocyte sedimentation rate were normal. The serum IgM, IgA, IgG, ang IgE concentrations were also normal. Antibodies measles virus were not detected. The cobalt col

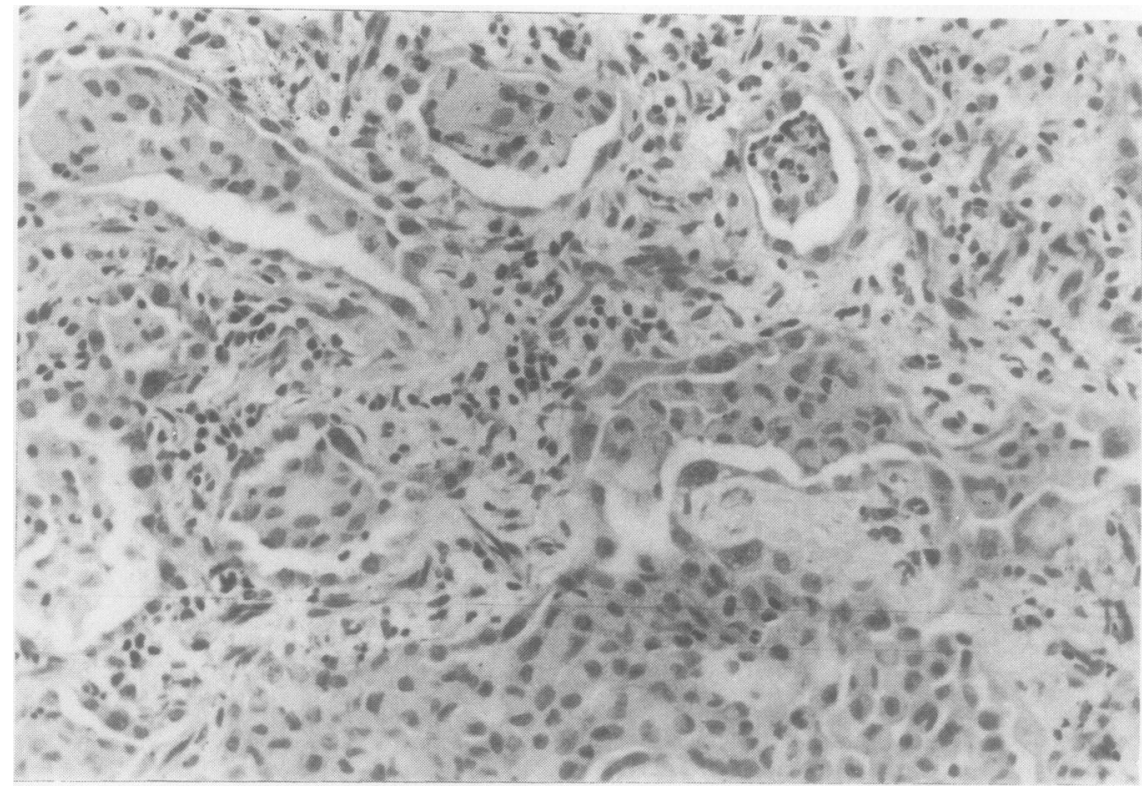

Fig 4 Lung biopsy specimen showing chronic interstitial pneumonia with noticeable "desquamative" features. (Haematoxylin and eosin, $\times 290$.) 


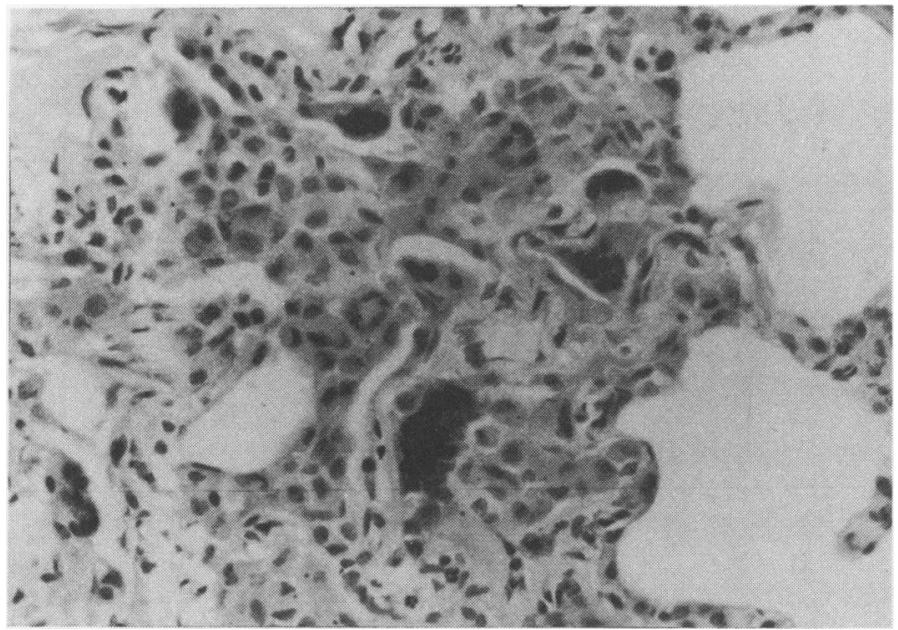

Fig 5 Lung biopsy specimen showing several syncytial nuclear clusters lining alveoli, which also contain many macrophages. (Haematoxylin and eosin, $\times 410$.)

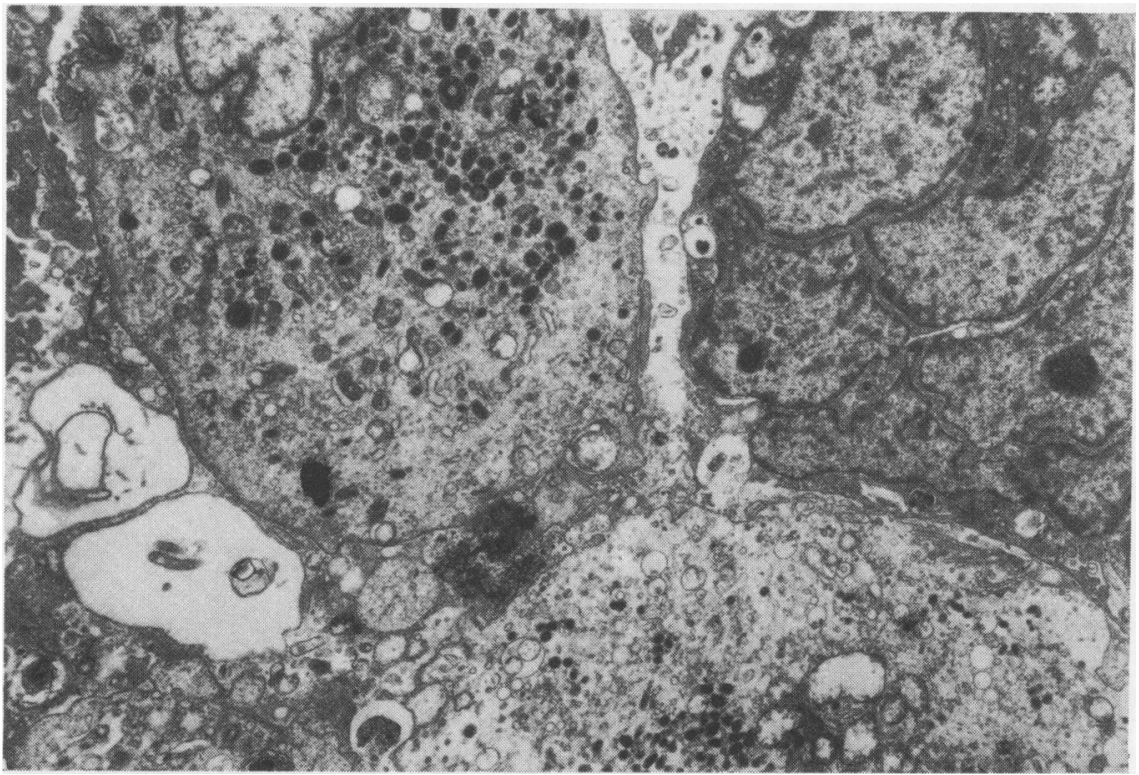

Fig 6 Lung biopsy showing two macrophages rich in lysosomes contrasting with a multinucleate type II cell (top right), which has more electrondense cytoplasm. (Electron micrograph, $\times$ 5300.)

centration in the urine was $76 \mathrm{nmol} / \mathrm{l}$. The $\mathrm{FEV}_{1}$ was $2930 \mathrm{ml}$, FVC $3070 \mathrm{ml}$, and KCO $1.5 \mathrm{mmol} \mathrm{min}^{-1}$ $\mathrm{kPa}^{-1} \mathrm{l}^{-1}$ (predicted $1 \cdot 56-2 \cdot 11$ ). He had no increase in his $\mathrm{FEV}_{1}$ after using bronchodilator drugs or any diurnal variation in his peak flow rate. The bronchoalveolar lavage fluid (table 2) showed small refractile non-birefringent particles within macrophages, $4 \%$ of which were multinucleate. Trans- mission electron microscopy confirmed that the multinucleate cells in the lavage fluid were macrophages. The cobalt concentration in one lavage sample was $12 \mu \mathrm{g} / 1$ but cobalt was not detected in another sample.

An open lung biopsy specimen showed filling of the alveoli by macrophages and eosinophils with a few multinucleate macrophages in the alveolar 


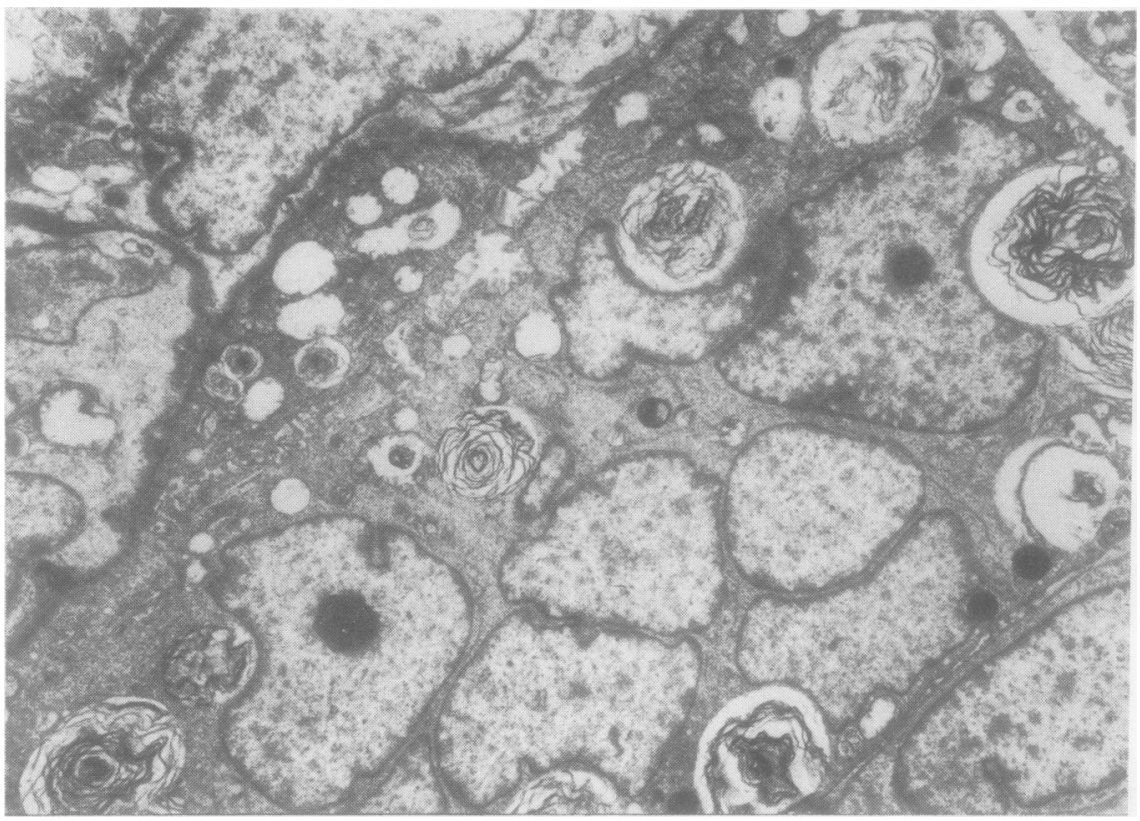

Fig 7 Lung biopsy specimen showing a multinucleate giant cell identified as a type II epithelial cell by its lamellar vacuoles, microvilli, and dearth of lysosomes. (Electron micrograph, $\times$ 5600.)

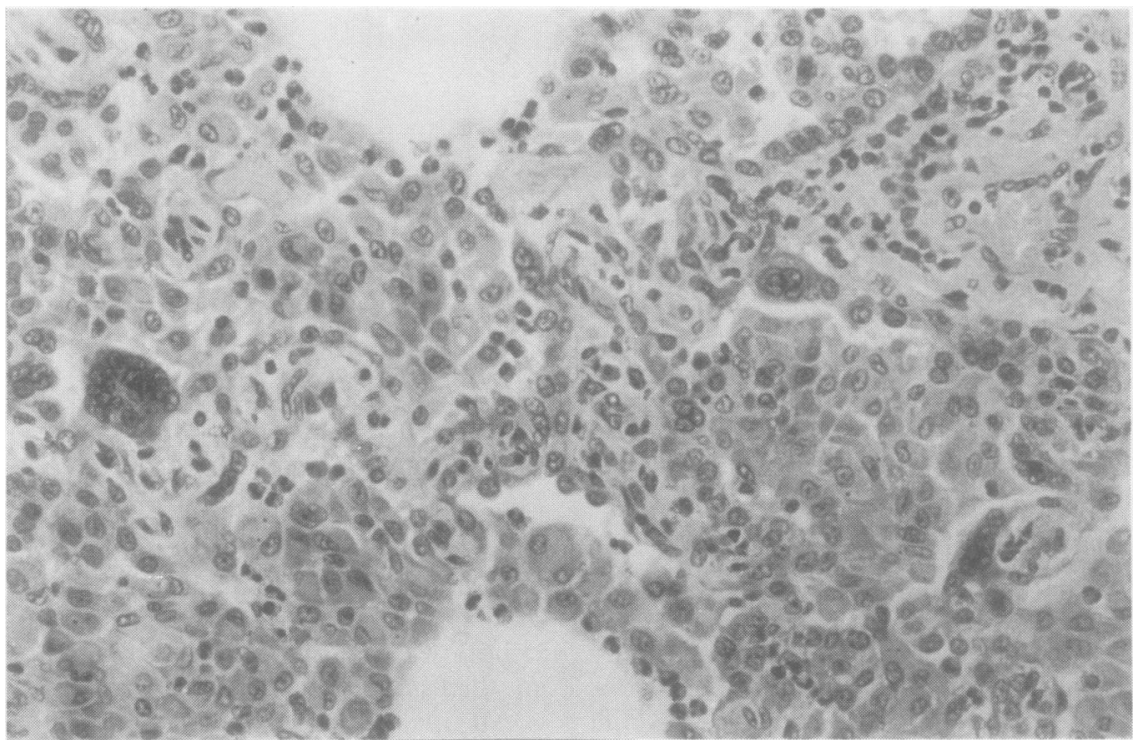

Fig 8 Lung biopsy specimen showing multinucleate alveolar lining cells and alveolar macrophage accumulation. (Haematoxylin and eosin, $\times 350$.) 


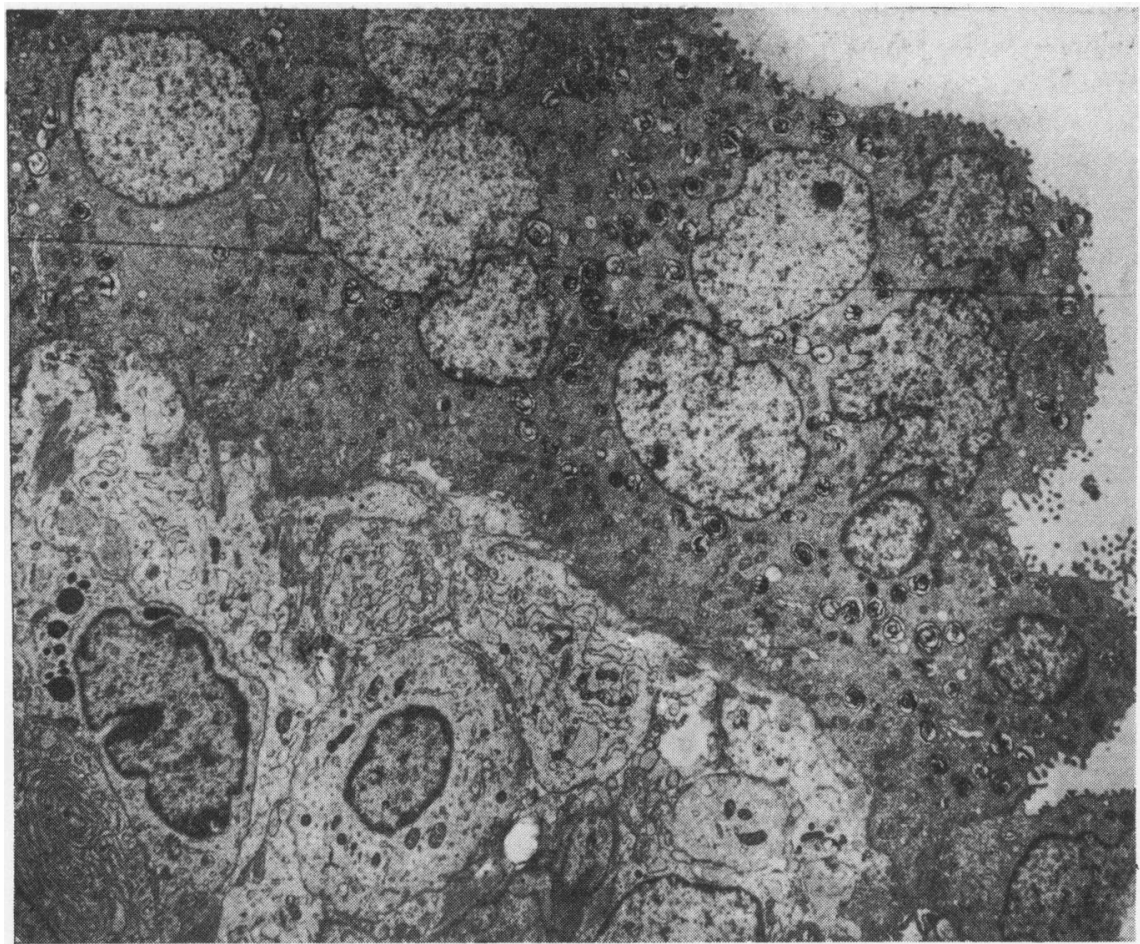

Fig 9 Multinucleate lining cell in a lung biopsy specimen, with the lamellar vacuoles and surface microvilli of a type II alveolar epithelial cell. (Electron micrograph, $\times$ 4250.)

lumen (fig 8). The alveolar interstitium was infiltrated by plasma cells and eosinophils and there were a few lymphoid follicles. Many alveoli were lined by a cuboidal epithelium with occasional prominent multinucleate lining cells. Transmission electron microscopy showed type II alveolar epithelial cell hyperplasia, multinucleate type II cells (fig 9) and multinucleate macrophages within the alveolar lumen. Elemental analysis detected many particles of tungsten, sometimes associated with titanium or cobalt.

\section{CASE 3}

A man of 48 , a non-smoker, presented with a fouryear history of progressive shortness of breath and a cough productive of a small amount of mucoid sputum. He had ground hard metal tools and drills on a diamond wheel for nine years. On examination there were bilateral crackles in his chest. His chest radiograph showed bilateral basal reticular shadowing, whereas a radiograph two years previously had shown only minimal changes. Haemoglobin concentration, total and differential white cell counts, and ESR were normal. An autoantibody screen was negative and no avian or Micropolyspora faeni precipitins were detected. Lung function tests showed a restrictive defect with an $\mathrm{FEV}_{1}$ of $2400 \mathrm{ml}$ (predicted 3070-4160 ml) and an FVC of $2600 \mathrm{ml}$ (pre- dicted 4150-5620). An open lung biopsy showed fairly severe interstitial lymphocytic infiltration and fibrosis with many macrophages in the alveolar spaces. Many of the alveolar macrophages formed multinucleate giant cells and occasionally on the walls of the alveoli small syncytial clusters of nuclei were observed, similar to the multinucleate epithelial cells seen in the first two cases; but no granulomas were seen. Black dust particles were seen in both mononuclear and multinuclear macrophages and polarising microscopy showed a small amount of birefringent dust. Electron microprobe analysis detected many tungsten and titanium particles. He was treated with prednisolone $30 \mathrm{mg} /$ day and two months later his exercise tolerance had improved from one to two flights of stairs; the radiological shadowing had decreased and his lung function had improved, his FVC being $3000 \mathrm{ml}$. He has been maintained on an average of $7.5 \mathrm{mg}$ per day of prednisolone for 14 years. During this time his symptoms were unchanged but his chest radiographs and lung function tests showed slight deterioration. $\mathrm{He}$ retired at the age of 62 , having continued working in the same job.

\section{CASE 4}

A 41-year-old Jamaican woman had been well until the age of 37 , when three months after starting work 
as a cutter and grinder of presintered hard metal she developed rhinitis and asthma. She had never smoked. Initially her symptoms developed one hour after she had started work and improved after she had left work. Her symptoms gradually became more severe and she was unable to work three years after starting employment. She was admitted to hospital for investigation when she had been away from work for nine months. She appeared normal on physical examination, and skin prick tests to common allergens gave negative results. The haemoglobin concentration; total and differential white cell counts; and serum IgG, IgM, IgA, and IgE concentrations were normal. A chest radiograph was normal. Lung function tests showed reversible airway obstruction. Bronchial provocation tests with $100 \mathrm{~g}$ of hard-metal powder for five minutes produced a $24 \%$ fall in $F E V_{1}$ immediately and a $42 \%$ fall at 10 hours. Despite avoidance of exposure she has continued to require treatment for intermittent attacks of asthma.

\section{CASE 5}

A 45-year-old man had complained of exertional dyspnoea with episodic cough and wheeze for five years. He had worked for 20 years mixing cobalt and tungsten powders and until a few years before he had smoked 40 cigarettes a day. On examination bilateral wheezes and basal crackles were heard in his chest. Skin prick tests to common inhalant allergens gave negative results. The chest radiograph showed fine nodular shadowing throughout both lung fields, more noticeable in the upper and mid zones. The haemoglobin concentration, total and differential white cell counts, and ESR were normal. Serum IgG, IgM, IgA, and IgE were normal. No autoantibodies or avian precipitins were detected in his serum. Lung function tests showed an obstructive ventilatory defect with an FEV of 1690 $\mathrm{ml}$ (predicted 110-4220), FVC of 2880 (predicted $3980-5390$ ), and an $\mathrm{FEV}_{\mathrm{l}} / \mathrm{FVC} \%$ of 58 . The alveolar-arterial oxygen difference widened on exercise.

His symptoms had no diurnal variation and he had noticed no improvement when away from work, but two-hourly daytime measurements of PEFR made over a six-week period showed diurnal and between-day variability with evidence of improvement when away from work at weekends. During this period the average PEFR during the week fell from $3201 / \mathrm{min}$ in the first week to $2701 / \mathrm{min}$ in the sixth week. In hospital PEFR spontaneously increased over four weeks to $4201 / \mathrm{min}$.

The findings at bronchoscopy were normal but a bronchial biopsy showed chronic inflammation. Bronchoalveolar lavage was performed after the patient had been away from work for three weel (table 2). Seventy-one per cent of the cells were neutrophils, $25 \%$ macrophages, $1.5 \%$ eosinophiles, and $1.7 \%$ lymphocytes. Numerous refractile par类 cles were present in $21 \%$ of the macrophages. Mi roprobe elemental analysis showed tungsten, iro? and occasionally tantalum. Cobalt was not detectêl within the cells or in the cell-free lavage fluid. Inha lation testing with $50 \mathrm{~g}$ of cobalt powder for five minutes produced a $17 \%$ fall in $\mathrm{FEV}_{1}$ at 50 minut and a $19 \%$ fall at 9 hours; no reaction was provoke by a five-minute inhalation test with $50 \mathrm{~g}$ of tungste carbide powder.

With reduced exposure to hard-metal dust and treatment with inhaled salbutamol and be $\overrightarrow{c_{-}}$ lamethasone, the patient has remained symptoun free; but lung function tests, although the values have improved, continue to show an obstructive ventilatory defect, the $\mathrm{FEV}_{1}$ being $2125 \mathrm{ml}$, FVE 3825 , and $\mathrm{FEV}_{1} / \mathrm{FVC} \%$ 56. His chest radiograp画 has not changed over two years.

\section{Discussion}

Interstitial lung disease has been reported in harष metal workers in several industrialised countries over the last 40 years. ${ }^{16-9}$ Most pathological info mation has been obtained at necropsy, when fibros has been the dominant feature; but there have bee occasional reports based on biopsies describing interstitial infiltrates with hyperplastic alveolof epithelium, cellular accumulation within alveoli, and giant cells of histiocytic appearance. ${ }^{7}$ Asthma he also been reported in hard-metal workers ${ }^{23}$ and evis dence that cobalt may be the responsible constitue of the hard metal is supported by the results of ow bronchial provocation tests. It has recently beein suggested that hard-metal pneumonitis is founf mainly in workers handling the metal before it 8 sintered, while asthma is seen in grinders of sintered hard metal. ${ }^{10}$ This is not borne out by our experience. Two of our patients handled sintered hard metal and developed interstitial lung disease; of to two who handled the presintered material, one ha्त asthma and one interstitial disease. The patient who mixed cobalt and tungsten powders before thas were sintered had both asthma and radiographwo opacities, the asthma being the more prominent. $\sigma$

Our first patient had interstitial lung disease with mural, luminal (so-called desquamative), and giant-cell features together with bronchiolitis oblit. rans. Our second patient showed similar interstitial lung disease, while the third had more advanced interstitial fibrosis and less noticeable luming1 giant-cell features but otherwise resembled patients 1 and 2. Mural and luminal features often coexist 
interstitial lung disease, ${ }^{11}$ and transition from desquamative to giant-cell interstitial pneumonia has been previously described. ${ }^{12}{ }^{13}$ Bronchiolitis obliterans is a well-recognised effect of inhaling noxious fumes ${ }^{14}$ and occupational factors are often implicated in interstitial lung disease. Asbestosis is typically a mural process, while appreciable luminal lesions have been reported in workers exposed to many dusts, including hard metal, ${ }^{7}$ asbestos, ${ }^{15}$ talc, ${ }^{16}$ and aluminium. ${ }^{17}$ Giant-cell transformation is an unusual feature of interstitial pneumonia but was briefly alluded to by Coates and Watson ${ }^{7}$ when they reported on lung biopsy specimens from hard-metal workers. In describing giant-cell interstitial pneumonia Liebow ${ }^{18}$ made no reference to occupation but we have learnt that several of his subjects had been employed in the hard-metal industry (personal communication from $\mathbf{J}$ Abraham, curator of the AA Liebow collection). Moreover, a tungstencarbide worker with giant-cell interstitial pneumonia was reported by Abraham and Spragg. ${ }^{19}$ Thus the interstitial lung disease of hard-metal workers appears to be particularly likely to have giant-cell features. Our electron-microscopy findings provide information on the nature of these giant cells. Two types were identified, macrophages and type II epithelial cells. The latter do not appear to desquamate very readily as only the former were identified in the lavage material. It is not clear whether either type of giant cell represents cell fusion or faulty cell division; but one macrophage contained within another, which we observed several times, may represent an early stage of cellular fusion. Multinucleate type II epithelial cells have previously been reported in measles pneumonia. ${ }^{20}$ This condition, however, typically affects infants and is characterised by prominent viral inclusion bodies, which were not seen in our hard-metal workers.

With regard to the constituent of hard metal responsible for the interstitial pneumonia, animal experiments suggest that cobalt is toxic to the lung and possibly exerts a synergistic effect when combined with tungsten carbide or titanium. ${ }^{21}{ }^{22}$ Cobalt is highly soluble in biological fluids, and after inhalation there is an initial phase of rapid urinary excretion over about two days. This is followed by an extended phase of low-level excretion. Cobalt was detected in lung tissue, bronchoalveolar lavage fluid, and urine in only one patient (case 2); but all the specimens were taken at least three weeks after the patients had stopped work, and cobalt is very soluble in biological fluids. ${ }^{23}$ The different cobalt concentrations present in the two lavage fluid specimens in the second case could be due to the presence of particulate cobalt in one specimen. Positive skin patch test responses to cobalt have been reported in hard-metal workers ${ }^{9}$ but one of our cases shows that this is not always a feature of those developing alveolar disease. It has recently been stated that the histological appearances of the lung resemble those of hypersensitivity pneumonitis. ${ }^{10}$ This was not true of our patients in that no granulomas were seen.

Review of previously reported cases suggests that the interstitial lung disease associated with exposure to hard metal is relatively uncommon, with a prevalence of only $7 \%$ in one industry, ${ }^{7}$ and that the progression of the disease is very variable. Radiological shadowing may progress slowly ${ }^{6}$ or very rapidly. ${ }^{?}$ Removal from exposure may result in radiological clearing but symptomatic and radiological deterioration has been reported after re-exposure. ${ }^{679}$ Our first patient developed a severe restrictive ventilatory defect after only 25 months' work with hard metal. Our fifth patient by contrast developed symptoms only after 15 years of working with hard metal, and although he had nodular shadowing on his chest radiograph his main clinical problem was asthma and his lung function tests showed an obstructive ventilatory defect.

There is evidence suggesting that cobalt is the causative agent of hard-metal workers' asthma. Work-related asthmatic symptoms have been described not only with hard metal ${ }^{23}$ but also in workers exposed to cobalt alone. ${ }^{24} 25$ In one of our cases we found that cobalt alone but not tungsten carbide gave a positive response in the bronchial provocation test. An allergic rather than a toxic basis for the asthmatic response is supported by a negative result in the bronchial provocation test in a patient (not reported in this study) who was suspected but not proved to have hard-metal asthma; this patient was exposed to $50 \mathrm{~g}$ of cobalt powder for 30 minutes without effect.

Our patients' asthmatic patterns show some similarity to other occupational asthmas. The fourth patient initially showed typical work-related symptoms but then developed severe perennial asthma despite having stopped work with hard metal, a pattern of asthma similar to that reported in the asthma induced by the Western red cedar. ${ }^{26}$ Our fifth patient did not recover completely at weekends but developed increasingly severe airways obstruction with very slow spontaneous recovery; similar patterns have been described in isocyanate asthma. ${ }^{27}$

Workers who develop interstitial lung disease or asthma due to hard metal should avoid further exposure. It has recently been suggested that pulmonary function tests are of doubtful value in the detection of early interstitial disease due to hard metal, ${ }^{28}$ but our first case was initially detected because of abnormal results in pulmonary function tests at work. Moreover, the first two cases had 
normal chest radiographs on presentation. Wé suggest that all hard-metal workers shoald have tregular lung function tests and radiological examinatioms. In doubtful cases, as in our first patient, bronchoalveolar lavage may be of diagnostic value. Bizarre multinucleate giant cells are a feature we have not previously encountered in lavage material. Serial chest radiograph examination and lung function tests are necessary for monitoring disease activity. Possibly alveolar lavage is useful in predicting the therapeutic response and in monitoring disease activity; in the first case after removal from exposure for one year and nine months' treatment with prednisolone refractile particles were still evident in macrophages, but the eosinophils and giant cells in the lavage fluid were greatly reduced. Interstitial disease associated with hard metal has often been treated with corticosteroids-sometimes, as in our first case, with apparently dramatic results. ${ }^{7}$ There have been no controlled trials, however, and corticosteroid treatment has generally coincided with cessation of occupational exposure. Our second patient improved dramatically after avoidance of exposure and without corticosteroids. Our first case shows that reexposure to hard metal may result in deterioration despite steroid treatment, whereas in the third case prednisolone appeared to slow the progression of the disease despite continued exposure. Asthma induced by hard metal may persist despite avoidance of further exposure and requires conventional treatment.

We are grateful to Drs $M$ Weinberg and A Brain, Chelsea College, for their assistance with electron microprobe analysis; Norman Smith and Eric Pryde, occupational medicine laboratory, Health and Safety Executive, for cobalt analysis; the Chest, Heart and Stroke Association for supporting the bronchoalveolar lavage study; and Sonia Neil for secretarial assistance.

\section{References}

1 Jobs H, Ballhausen C. Powder metallurgy as a source of dust from the medical and technical standpoint. Vertravenargt 1940;5:142-148.

${ }^{2}$ Bruckner HC. Extrinsic asthma in a tungsten carbide worker. J Occup Med 1967;9:518-9.

${ }^{3}$ Coates EO, Sawyer HJ, Rebuck JN, Kvale PA, Sweet LW. Hypersensitivity bronchitis in tungsten carbide workers. Chest 1973;64:390.

4 Haslam PL, Turton CWG, Lukoszek A, Salsbury AJ, Dewar A, Collins JV, Turner-Warwick M. Bronchoalveolar lavage fluid cell counts in cryptogenic fibrosing alveolitis and their relation to therapy. Thorax 1980;35:328-339.

${ }^{5}$ Davies RJ, Hendrick DJ, Pepys J. Asthma due to inhted chemical agenter ampicillin, bencyl penicillis 6-qmipo- popicillanic acd and related substances. Cxis Altery $1974 ; 4: 227,47$.

- Bech AO, Kipling MD, Heather JC. Hard metal diseaseे Br J Ind Med 1962;19:239-52.

${ }^{7}$ Coates EO, Watson JHL. Diffuse interstitial lung dis ease in tungsten carbide workers. Ann Intern Mea 1971;75:709-16.

${ }^{8}$ Coates EO, Watson JHL. Pathology of the lung in tung sten carbide workers using light and electron micros copy. J Occup Med 1973;15:280-6.

- Sjogren I, Hillerdal G, Andersson A, Zetterström Qิ Hard metal lung disease: importance of cobalt in coof ants. Thorax 1980;35:653-9.

${ }^{10}$ Scherrer M, Maillard J-M. Hart metall-Pneumopathie Schweiz Med Wochenschr 1982;112:198-207.

" Scadding JG, Hinson KFW. Diffuse fibrosing alveolitis (diffuse interstitial fibrosis of the lungs). Correlation of histology at biopsy with prognosis. Thorag 1967;22:291-304.

12 Reddy PA, Gorelick DF, Christianson CS. Giant cett interstitial pneumonia (GIP). Chest 1970;58:319-2 Z

13 Wigger HJ, Berdon WE, Ores CN. Fatal desquamative interstitial pneumonia in an infant. Arch Pathol Lo Med 1977;101:129-32.

14 Spencer H. Pathology of the lung. 3rd ed. Oxford: Pergamon Press, 1977:660-2.

15 Corrin B, Price AB. Electron microscopic studies in des quamative interstitial pneumonia associated with asbestosis. Thorax 1972;27:324-331.

${ }^{16}$ FitzGerald MX, Carrington CB, Gaensler ES. Environmental lung disease. Med Clin North A $\overline{\bar{m}}$ 1973;57:593-622.

${ }^{17}$ Herbert A, Sterling GM, Abraham J, Corrin B. De 8 quamative interstitial pneumonia in an aluminium welder. Hum Pathol 1982;13:694-9.

${ }^{18}$ Liebow AA. Definition and classification of interstiti pneumonias in human pathology. Prog Resp R 1975;8:1-33.

${ }^{19}$ Abraham JC, Spragg RG. Documentation of envirop. mental exposure using open biopsy, transbronchiz biopsy and bronchopulmonary lavage in giant ced interstitial pneumonia (GIP). Am Rev Respir D\%s 1979;119:197 (abstract).

${ }^{20}$ Archibald RWR, Weller RO, Meadow SR. Measles pneumonia and the nature of inclusion-bearing giabi cells: a light- and electron-microscope study. $J$ Patha 1971;103:27-34.

${ }^{21}$ Schepers GWH. The biological action of particulate cobalt metal. Arch Ind Health 1955;12:127-133. $\frac{7}{2}$

${ }^{22}$ Schepers GWH. The biological action of tungsten carr. bide and cobalt. Arch Ind Health 1955;12:140-1460

${ }^{23}$ Harding HE. Notes on the toxicology of cobalt metal. BP $J$ Ind Med 1950;7:76-78.

${ }^{24} \mathrm{Key}$ MM. Some unusual allergic reactions in industrix Arch Dermatol 1961;82:57-60.

${ }^{25}$ Verhamme EN. Contribution to the evaluation of the

toxicity of cobalt. Cobalt 1973;2:29-32.
${ }^{26}$ Chan-Yeung M. Fate of occupational asthma. Am RE् Respir Dis 1977;116:1023-9.

${ }^{27}$ Burge PS, O'Brien IM, Harries MG. Peak flow rate records in the diagnosis of occupational asthma due 8 isocyanates. Thorax 1979;34:317-23.

${ }^{28}$ Payne LR. The hazards of cobalt. J Soc Occup Meg 1977;27:20-5.

${ }^{29}$ Cotes JE. Lung function. Oxford: Blackwell, 1979. 